\title{
TOMÁŠ BERÁNEK
}

\section{EXPERTNÍ SYSTÉMY A JEJICH UPLATNĚNÍ V KARTOGRAFII}

T. B e rá n e k : Expert Systems and Their Cartographic Applications. - Sborník ČGS, 100, 1, pp. 35 - 41 (1995). - Expert systems are computer programs for reconstructing the expertise within a limited domain. They are able to replace the work of a qualified specialist. Such systems have complicated internal architecture. Many types of expert systems have been developed for different disciplines. Cartographic expert systems are primarily used in label placement and in some procedures of generalization.

KEY WORDS: expert system - computer-assisted cartography - rule-based system - cartographic design - generalization - label placement.

\section{1. Úvod}

V posledních letech se $v$ moderní odborné literatuře stále více objevuje termín expertní systém. V některých vědních oborech, např. v medicíně, jsou již expertní systémy hojně rozšîreny, ale existují i takové vědy, v nichž se tímto tématem zabývá pouze velmi úzký okruh výzkumníků. K nim patří rovněž geografie a kartografie. Ve Sborníku c. 4/1992 byly expertní systémy již okrajově zmíněny (Kolejka, 1992).

Již počátkem šedesátých let tohoto století vzniklo především v USA a v Japonsku několik přistupů založených na použití počítačů, které byly určeny k řešení všeobecných problémů jako jsou matematické důkazy různých teorií nebo řešení šachových úloh. Ty lze považovat za předchůdce prvních expertních systémů, na jejichž projektu se začalo pracovat zhruba v polovině šedesátých let. Vznikly první, velice jednoduché expertní systémy, z nichž nejznámnější je DENDRAL, používaný v organicko-chemické analýze pro odvozování struktury organických molekul podle jejich chemických vzorců a MACSYMA, který zjednodušuje algebraická vyjádření. Za „otce expertních systémů“ lze však považovat program MYCIN, vyvinutý na Stanfordské univerzitě pro diagnózu a terapii bakteriálních infekcí krve a žloutenky (Barr, Feigenbaum, 1982).

Zkušenosti získané prací s těmito expertními systémy první generace vedly koncem sedmdesátých let ke zkrácení doby vývoje podobných systémů. Postupně se expertní systémy rozšîrily $i$ do dalších vědních oborư a $v$ dnešní době jsou již široce používány. Lze očekávat, že v příších letech se jejich evoluce ještě více urychlí.

\section{Definice expertního systému}

Co tedy rozumíme pod pojmem expertní systém? Obecně lze říci, že expertní systém je počítačový programový systém vzniklý na základě odborných znalostí, který vytvárí řešení určitého problému ve specifické oblasti ve stejné kvalitě jako expert vyškolený $\mathrm{v}$ tomto oboru. Tomu odpovídají $\mathrm{i}$ definice $\mathrm{v}$ odborné literatuře:

„Expertní systém je pokládán za počítačové ztělesnění na základě znalostí odborníka v takové formè, že systém může nabídnout inteligentní radu nebo učinit inteligentní 
rozhodnutí o průběžných funkcích. Systém je schopný na požádání vysvětlit svůj vlastní postup uvažování zpưsobem, který je uživateli okamžitě srozumitelný.“ (Smart, Langeland-Knudsen, 1986).

„Expertní systém je počítačový program $\mathrm{v}$ zavedeném jazyce, který provádí expertizy v úzce ohraničeném oboru.“ (Brownston et al., 1985).

Probíhající expertiza je schopna nahradit člověka-experta, který se zhruba 5-10 let zabývá danou problematikou. Expertní systém je schopen používat jeho metodologii, tzn., že získá „lidskou zručnost“, která mu zaručuje být opravdovým specialistou a soustředit se na omezenou řadu problémů (Luger, Subblefield, 1989). Podobně jako u člověka jsou znalosti systému teoretické i praktické, zdokonalené prostřednictvím zkušeností v dané oblasti. Avšak na rozdíl od člověka není schopen se naucit vlastní zkušenosti. Ty musí získávat prostřednictvím svého tvůrce, lidského experta, který ho naplňuje.

\section{Vnitřní struktura expertního systému}

Při práci s expertními systémy se setkáváme s množstvím nových pojmů, které je nutno přesně vymezit. Termínem znalost (knowledge) označujeme každou informaci, která vstupuje do systému a je specifická pro konkrétní oblast, v níž expertní systém pracuje. V literature se často užívá označení systém na základě znalostí (rule-based system), což je synonymum pro expertní systém. Znalosti rozlišujeme vyjádřené a procedurální. Vyjádřená znalost (declarative knowledge) je taková informace, kterou lze uložit do paměti nebo opětovně vyvolat, ale aby byla efektivní pro činnost systému, musí být vyjádřena pomocí procedurální znalosti. Procedurální znalost (procedural knowledge) se může bezprostředně zapojit do činnosti systému jako údaj užitím vyjádřené znalosti, ale nemůže být zkoumána. V kartografickém expertním systému je vyjádřenou znalostí např. čarový prvek (vodní tok, železnice), kdežto procedurální znalost má hodnotu algoritmu, kterým se tento prvek zaznamenává.

Produktivní pamčt (production memory) je pamět, vi níž je uložena skupina pravidel, přičemž pod pojmem pravidlo (rule) rozumíme vyjadřovací jednotky, které jsou užívány k dekódování procedurálních znalostí. Každé pravidlo vytváří řízený pár výstupů: levostranný $v$ případě, že pravidlo neplatí, vrací postup zpět a pravostranný při opačné situaci umožňuje provedení následující operace.

Jedním z hlavních problémů činnosti expertního systému je skutečnost, že ve stejnou dobu je nutné posuzovat i několik pravidel najednou. Jinými slovy může nastat situace, kdy se jedno pravidlo uplatňuje na úkor druhých. Proto dokonalé systémy řeší tento problém zavedením cyklu poznávacího děje (recognize-act cycle). Při něm jsou všechna pravidla nejprve porovnávána s údaji $\mathrm{v}$ databázi. Upřednostnělé pravidlo je spuštěno a vstupuje do konfliktní skupiny. Pokud se zde setká více spuštěných pravidel, je zapotřebí provést důslednou formu konfliktního rozhodnutí a vybrat jedno pravidlo, které může být vypuštěno, tzn., že dojde ke zjištění, zda pravidlo platí či nikoliv. Po vypuštění pravidla se cyklus opakuje, dokud se nevyčerpají všechna pravidla shromážděná $v$ konfliktní skupině. Výběr pravidla a rozhodnutí o jeho vypuštění vykonává závěrečný nástroj (inference engine). Představuje ho část aplikačního programu, který ve vztahu k nově odvozené znalosti provádí úkony jako jsou vstupy, výstupy, kontrola a optimalizace.

Znalostní báze, globální databáze a závěrečný nástroj, který vykonává cyklus poznávacího děje, tvoří produkční systém celého expertního systému, jehož jednotlivé prvky přehledně ukazuje obr. 1. Produkční systém je schopen na závěr uvést pomocí justifikátoru (justifier) základní vysvětlení pro uživatele, $v$ němž vypočítává pravidla a vyřešené problémy $\mathrm{v}$ pořadí jejich výběru a vypuštění. Někteří autoři pokládají toto vysvětlení za 


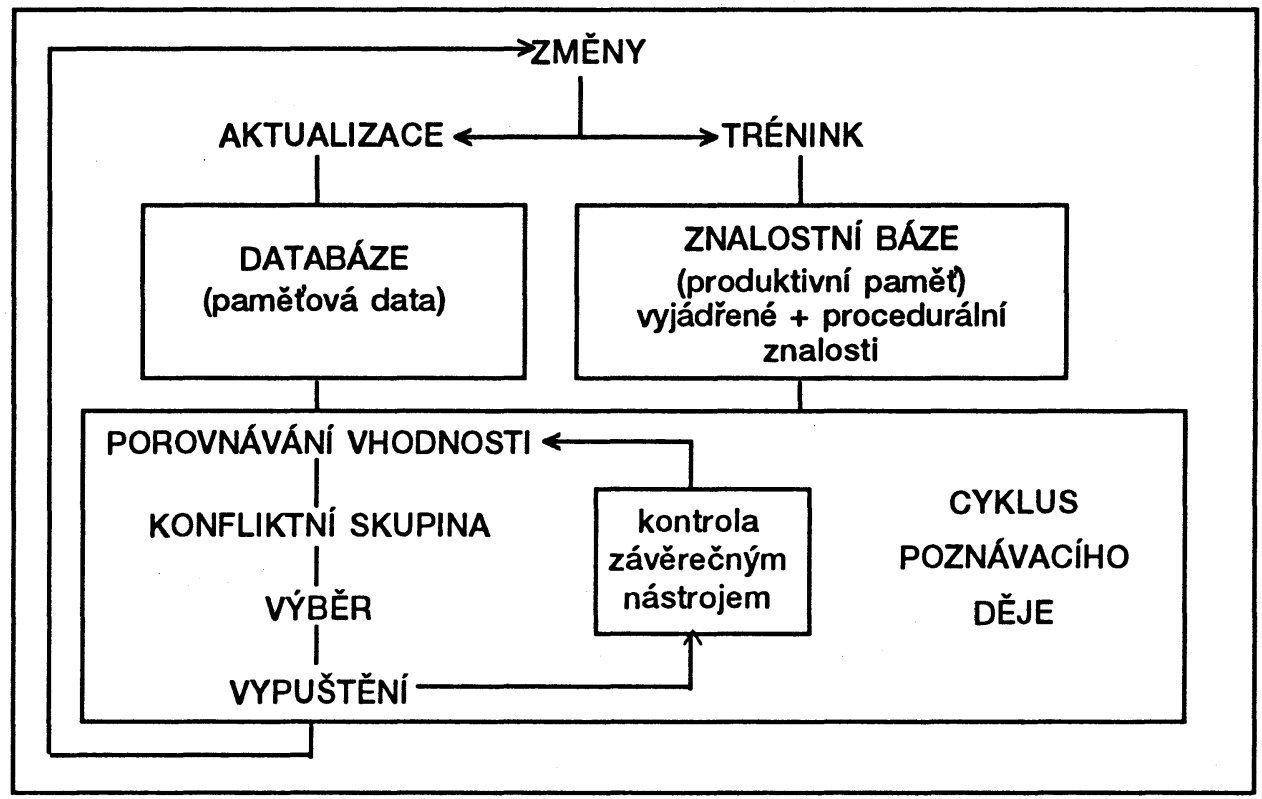

Obr. 1 - Prvky expertního systému (podle Brownston et al., 1985).

základní rys expertního systému (např. Brachman et al., 1983). Vysvětlení je proces, popisující jak systém dosáhl svých závěrů a proč dával uživateli případné doplňující otázky. Jeho úkolem je potvrdit strategii řešení problému nebo rozhodnutí o něm. Navíc může uživatele tuto strategii naučit.

\section{Typy expertních systémů}

Široké možnosti uplatnění expertních systémů daly vzniknout značnému množství jejich různých typů tak, jak odpovídaly potřebám jednotlivých vědních oborů. Tabulkový prehled hlavních typů expertních systémů se základními kategoriemi jejich aplikací přináší obr. 2.

Interpretační expertní systém odvozuje situaci popsanou pozorovatelem. V to může být zahrnuto vysvětlení chemické struktury, analýza představ, porozumění řeči, interpretace signálů a další druhy inteligenční analýzy. Systém vysvětluje pozorované údaje pomocí určení symbolických významů popisujících situaci nebo stav.

Předpovědní expertní systém je schopen předpovídat počasí, demografický vývoj, dopravní zatížení, výnosy obilí, popř. i provádět vojenské prognózy. Je pro něj typické pracovat s dynamickým modelem, jehož parametry mají hodnoty vztahující se k dané situaci. Důsledky odvozuje na základě dalšího možného vývoje a při ignoraci pravděpodobných odhadů může vytvořit velké množství možných scénáři.

Diagnostický expertní systém zahrnuje mezi jiným lékařskou, elektronickou, strojovou či softwarovou diagnózu. Dává do relace pozorované výchylky v chování s podloženými případy, přičemž bud srovnává chování s určitou diagnózou nebo se znalostmi příznakư nejrůznějších vad.

Různé objekty vyvíjí tvưrčí expertní systém. Musí při tom dodržet podmínky navrženého problému, např. při kresbě map, návrhu budov nebo při tvorbě rozpočtu. Systém vytvárí popis objektů v rozmanitých návaznostech na jiné objekty a ověruje, zda tyto 


\begin{tabular}{|c|c|}
\hline typ systému & aplikace \\
\hline INTERPRETAČNI & odvození situace popsané sensory \\
\hline PŘEDPOVĚDNI & odvození pravděpodobných následků dané situace \\
\hline DIAGNOSTICKÝ & odvození systému špatných funkcí pozorovaného objektu \\
\hline TVU゚RČ́ & sestavení objektu za určitých okolnostr \\
\hline PLÁNOVACI & návrhová činnost \\
\hline MONITOROVACI & porovnávání pozorování a kritických vlastností objektu \\
\hline NÁPRAVNÝ & předepsání náprav objektu při špatné funkěnosti \\
\hline OPRAVNÝ & vyhotovení plánu opravy \\
\hline PORADENSKÝ & stanovení diagnózy a náprava chování objektu \\
\hline KONTROLNI & interpretace, předpovẽđ, monitoring a náprava chování objektu \\
\hline
\end{tabular}

Obr. 2 - Typy expertních systémů.

objekty odpovídají zadaným podmínkám. Systém rovněž dokáže nazírat na možné chování navrhovaného objektu v jeho cílové podobě.

Plánovací expertní systémy se specializují na návrhy takových objektů, které jsou dynamické a jejich dynamičnost lze vyjádřit matematickou funkcí. Sem spadá automatické programování, robotika, projektování komunikací i vojenské techniky. Také tyto systémy sestavují modely pro zjištění následků chování plánované činnosti.

Mnoho monitorovacích expertních systémů je využíváno v nukleární energetice, letecké dopravě, nemocnicích, daňovém managementu. Takový systém srovnává chování pozorovaného objektu s vlastnostmi, které se zdají být rozhodující pro úspěšnost plánovaného výsledku. Tyto kritické vlastnosti odpovídají potenciálním chybám v plánu a vytvářejí zranitelná místa objektu, které systém identifikuje dvěma zpưsoby: Při prvním dochází $\mathbf{k}$ porušení napodobených podmínek, což anuluje základní rozumový postup plánu. Druhý způsob nastává, když vznikající efekt narušuje plánované okolnosti.

Nápravné expertní systémy předpisují nápravu špatných funkcí objektu. Závisí na plánovacích, tvưrčích a předpovědních schopnostech vytvořit odpovídající podmínky pro korekci diagnostického problému. Tyto systémy se často skládají pouze ze znalostní báze a textového editoru, a proto nebývají považovány za expertní systémy. Jednoduché jsou i opravné expertní systémy, jejichž doménou je vyhledání závad a předepsání oprav samohybných, elektrických, aviatických a počítačových zařízení.

Chování jedinců, zejména studentů, rozebírají a napravují poradenské expertní systémy. Typická je pro ně konstrukce hypotetické závislosti mezi úrovní znalostí studentů a jejich chováním. Mohou zjištovat oblasti zájmu studentů, slabiny v jejich znalostech a určovat jejich nápravy.

Každé chování může přizpůsobivě řídit kontrolní expertní systém. Na základě kontroly přesné situace předvídá následky a vývoj do budoucna a určuje možnosti regulace či nápravy. Zpětně monitoruje navržené a provedené zásahy, zda a nakolik byly úspěšné. Je používán např. při kontrole letecké dopravy, obchodního managementu, zbrojní výroby či rưzných misí.

\section{Kartografický expertní systém}

Otázku, zda kartografický expertní systém je možný, si kladlo a stále klade mnoho autorů (např. Fisher, Mackaness, 1987, nebo Muller, Johnson, Vanzella, 1986). Expertní systém se může $v$ kartografii uplatnit jedině tehdy, pokud je schopen produkovat vysoce kvalitní mapy s minimálními zásahy člověka (Buttenfield, Mark, 1986). 
Úplný kartografický expertní systém by měl být schopný tvorby bez jakékoliv lidské intervence, a to map v̌̌ech typů, počínaje grafy a jednoduchými počítačovými mapkami až po vysoce kvalitní nástěnné mapy a atlasy. Systém by měl produkovat mapy pro libovolnou skupinu dat a situaci. Výsledné mapy by měly být minimálně na takové úrovni jako mapy vytvořené profesionálními kartografy a základní mapové informace by měly pocházet $\mathrm{z}$ jednoduchých databází. Kartografický expertní systém by měl uživateli poskytovat specifikovaná měřítka, zobrazení, barvy, značky a také by měl umět správně reagovat $v$ případě chybného či neúplného zadání. Ideální by bylo, kdyby systém vytvořil vhodný výběr kartografických vyjadřovacích prostředků dokonce i tehdy, když si to uživatel nepřeje. Ovšem je jasné, že vývoj kartografického expertního systému s takovými schopnostmi je monumentální úkol, který může řešit početný tým expertů s velkými investicemi po dobu několika desítek let.

Porovnání možného a již existujícího uplatnění expertních systémů $v$ jednotlivých oblastech automatizované kartografické tvorby ukazuje obr. 3. V užívání jsou jednoduché algoritmy pro generalizaci čarových prvků a pro rozhodování o kartografickém výběru geometrických značek a př́pustných hodnotách jejich zjednodušení. Úrodná půda pro expertní systémy je v oblasti symboliky, zejména při kódování vybraných symbolů na základě semiologického uvažování. Způsob rozhodování mezi různými způsoby vyjádření tematických dat je neustále vyvíjen a testován, rovněž výběr barev či barevných segmentů. Největší uplatnění expertních systémů je možné při konečném zpracování map. Zde se expertní systémy využívají při přemistování prvkủ obsahu mapy v rámci harmonizace a jejich současné nejdůležitější uplatnění je při umistování popisu, nebơ podléhá jednoduchým zákonitostem. Jsou známy mnohé praktické výsledky - vytištěné mapy.

Kartografické expertní systémy mohou být rozděleny do tří základních kategorií (Fisher, Mackaness, 1987):

a) Systémy pro interpretaci mapových a prostorových dat, vytvořené pro různý stupeň porozumění těmto datům, např. MAPSEE (popsaný v Havens, Mackworth, 1983) nebo KBGIS (Smith et al., 1984).

b) Poradní systémy pro mapovou tvorbu. Jedná se o naučné systémy, které pomocí čistě verbální konzultace instruují uživatele jak konstruovat mapy různých druhů, zobrazení apod. ve vztahu k určitému typu dat (Muller, Johnson, Vanzella, 1986).

\begin{tabular}{|c|c|c|c|c|}
\hline \multicolumn{3}{|c|}{ složky kartografické tvorby } & $A$ & $B$ \\
\hline $\begin{array}{l}\text { SYMBOLIKA } \\
\text { TVORBA }\end{array}$ & $\begin{array}{l}\text { ZJEDNODUŠENÍ } \\
\text { KLASIFIKACE } \\
\text { NAVÝŠENI } \\
\text { STRATEGIE KÓD } \\
\text { KONCEPČNI OMY } \\
\text { SITUAČNÍ OMEZ } \\
\text { VYKRESLENÍ } \\
\text { PROSTOROVÉ US } \\
\text { HARMONIZACE } \\
\text { UMISŤOVÁNÍ PO } \\
\text { VIZUÁLNI KONT }\end{array}$ & $\begin{array}{l}\text { ZMENŠENÍ } \\
\text { VÝBĚR } \\
\text { REPOZICE } \\
\text { SHLUKOVÁNI } \\
\text { ROZDĚLENÍ } \\
\text { PŘEKRYT } \\
\text { INTERPOLACE } \\
\text { VYROVNÁVÁNI } \\
\text { REKONSTRUKCE } \\
\text { OVÁNÍ } \\
\text { EZENÍ ZNAČEK } \\
\text { ENÍ ZNAČEK } \\
\text { POŘ́LÁNÍ } \\
\text { PISU } \\
\text { RAST }\end{array}$ & $\begin{array}{l}\text { malé } \\
\text { velké } \\
\text { malé } \\
\text { střední } \\
\text { střední } \\
\text { malé } \\
\text { malé } \\
\text { střední } \\
\text { střední } \\
\text { střední } \\
\text { velké } \\
\text { střední } \\
\text { malé } \\
\text { střední } \\
\text { velké } \\
\text { velké } \\
\text { střední }\end{array}$ & $\begin{array}{l}\text { Žádné } \\
\text { střední } \\
\text { žádné } \\
\text { Žádné } \\
\text { Žádné } \\
\text { žádné } \\
\text { žádné } \\
\text { žádné } \\
\text { malé } \\
\text { střední } \\
\text { Žádné } \\
\text { malé } \\
\text { žádné } \\
\text { Žádné } \\
\text { střední } \\
\text { velké } \\
\text { žádné }\end{array}$ \\
\hline
\end{tabular}

$A=$ možné uplatnění

$\mathrm{B}=$ existující uplatnění

Obr. 3 - Možnosti uplatnění expertních systémů v kartografické tvorbě (podle Mark, Buttenfield). 
c) Systémy pro plně automatizovanou mapovou tvorbu, které se zabývají jednou fází mapové tvorby, dobře vymezitelnou a snadno matematicky definovatelnou. Do této skupiny patři ACES (Pfeferkorn, 1985), AUTONAP - expertní systém pro automatické umistování názvů (Freeman, Ahn, 1984), PROLOG se stejným zaměřením (Jones, Cook) nebo jiný systém pro generalizaci (Nickerson, Freeman, 1986).

Závěrem je nutno dodat, že kompletní kartografický expertní systém v takové podobě, jak je popsán výše, se nemůže skládat z elementárních systémů společně sestavených, ale musí to být jediný systém, který je schopen zvažovat všechny postupy kartografické tvorby na všech stupních sestavování map. Pro vývoj kompletních systémů je nutná těsná spolupráce kartografů a programátorů, přičemž úkolem kartografư je vytvoǒit široce přijímané a jasné metody, na jejichž základě by bylo možné tyto postupy naprogramovat.

\section{Literatura:}

BARR, A., FEIGENBAUM, E. A. (1982): The Handbook of Arteficial Intelligence, Pitman, London BRACHMAN, R.J. et al.(1983): What Are Expert System? In: HAYES-ROTH, F., WATERMAN, D. A., LENAT, D. B. (Eds.): Building Expert System, Addison-Wesley Publishing Co. Inc., s. 31-57

BROWNSTON, L., FARELL, R., KANT, E., MARTIN, N.(1985): Programming Expert System in OPS 5: An Introduction to Rule-Based Programming, Addison-Wesley, Reading (Mass.)

BUTTENFIELD, B. P., MARK, D. M. (1991): Expert Systems in Cartographic Design. In: TAYLOR, D. R. F. (Ed.): Geographic Information Systems: The Microcomputer and Modern Cartography, Pergamon Press, Exeter, s. 129-150

FISHER, P. F., MACKANESS, W. A. (1987): Are Cartographic Expert Systems Possible? In: CHRISMAN, N. R. (Ed.): Proceedings, 8th International Symposium on Computer-Assisted Cartography (AUTO-CARTO 8), Baltimore, s. 530-534

FREEMAN, H., AHN, J. (1984): AUTONAP - An Expert System for Automatic Name Placement. In: Proceedings of the International Symposium on Spatial Data Handling, Zürich Vol. 2, s. 544-569

HAVENS, W., MACKWORTH, A. (1983): Representing Knowledge of the Visual World. In: Computer, Vol. 16, s. 90-96

HAYES-ROTH, F., WATERMAN, D. A., LENAT, D. B. (Eds.) (1983): Building Expert System, Addison-Wesley Publishing Co. Inc.

JONES, C. B., COOK, A. C.: Rule-Based Geographic Name Placement with Prolog. In: Proceedings of Auto-Carto 9 Falls Church, Virginia, s. 231-240

KOLEJKA, J. (1992): Expertní systémy v geografické informatice. Sborník ČGS, 97, Česká geografická společnost, Praha, 4/1992, s. 253-260

LUGER, G. F., SUBBLEFIELD, W. A. (1989): Arteficial Intelligent and the Design of Expert Systems, Benjemin/Cummings Publ. Co. Inc., Redwood, $662 \mathrm{s.}$

MARK, D. M., BUTTENFIELD, B. P.: Design Criteria for a Cartographic Expert System. In: Proceedings, 8th International Workshop on Expert Systems and Their Applications, Avignon, Vol. 2, s. 413-425

MITÁŚOVÁ, I., VEVERKA, B., PEZLAR, Z. (1990): Základy teórie systémov a kybernetiky s aplikáciemi v geodézii a kartografii. Alfa, Bratislava, $248 \mathrm{~s}$.

MULLER, J. C., JOHNSON, R. D., VANZELLA, L. R. (1986): A Knowledge-Based Approach for Developing Cartographic Expertize. In: Proceedings of the Second Symposium on Spatial Data Handling, IGU, Williamsville, s. 557-571

NICKERSON, B. G., FREEMAN, H. (1986): Development of a Rule -Based System for Automatic Map Generalization. In: Proceedings, Second International Symposium on Spatial Data Handling, Seattle, s. 537-556

PFEFERKORN, C. et al. (1985): ACES: A Cartographic Expert System. In: Proceedings of the Seventh International Symposium on Automated Cartography (AUTO CARTO 7), s. 399-407

PUPPE, F. (1993): Systematic Introduction to Expert Systems, Springer Verlag, Berlin/Heidelberg, 356 s.

SMART, G., LANGELAND-KNUDSEN, J. (1986): The CRI Directory of Expert Systems, Learned Information Ltd., Oxford, $346 \mathrm{s.}$

SMITH, T. R. et al. (1984): Arteficial Intelligence and Its Applicability to Geographical Problem Solving. In: Professional Geographer, Vol. 36/1984, s. 147-158 


\section{Summary}

\section{EXPERT SYSTEMS AND THEIR CARTOGRAPHIC APPLICATIONS}

The term ,expert systems“ is frequently quoted in many recent publications. Expert systems are used in a number of scientific disciplines. In some branches, however, the use of expert systems is not yet widespread - and this is the case of geography and cartography, too.

What does the expression ,expert system" mean? It is a computer program for reconstructing the expertise within a limited domain. It achieves to replace the work of a qualified specialist. Expertise realized by an expert system is able to be of the same quality or better than the work of human expert with a long experience in the respective field. Operating of such a system, however, requires the human experience.

The internal architecture of expert systems is a very complicated. It consists on many elements; the knowledge base and the control system are the most important ones. The control system is built up by recognize-act cycle and inference engine. The expert system communicates with its user by a justifier.

Many types of expert systems for different disciplines have been developed. Systems for interpretation, prediction, diagnosis, design, planning, monitoring, debugging, repair, instruction and control expert systems exist.

Some authors ask whether cartographic expert systems can really exist. Expert systems can be applied in computer-assisted cartography only if they can produce high quality maps without human assistance. At present these systems are used in many phases of map design and production. It includes generalization (line simplification and symbol reduction), decision-making about the way of representation of thematic data, selection of colours and above all label placement. A complex cartographic expert system, however, should not consist on connected partial system only. Development of such a complex system demands close collaboration between cartographers and computer technicians over a long time.

Fig. 1 - Elements of expert system.

Fig. 2 - Types of experts systems.

Fig. 3 - Possibilities of expert systems applications in cartographic production.

(Pracoviště autora: Katedra kartografie a geoinformatiky, Př́rodovědecká fakulta UK, Albertov 6, 128 43 Praha 2.) 